\title{
Muuta kirjastoja, muutat yhteiskuntia - IFLA 2018 Kuala Lumpurissa
}

\author{
Vuoden 2018 IFLA konferenssi pidettiin Kuala Lumpurissa, \\ Malesiassa. Paikalle oli kokoontunut reilu 3500 konferenssivie- \\ rasta yli sadasta maasta. Erilaisia tapahtumakokonaisuuksia oli \\ liki kolmesataa aihekohtaisista sessioista toimielinten tapaami- \\ siin ja lyhyisiin seitsemän minuutin lightning talks -pikaesitel- \\ mien kokonaisuuksiin. Lisäksi vielä epäviralliset tapahtumat ja \\ vierailut suuren metropolin kirjastoihin ja nähtävyyksiin täytti- \\ vät nopeasti vierailijan kalenterin.
}

M alesia on kansakuntana varsin nuori, se itsenäistyi vuonna 1957. Kulttuuriltaan Malesia on hyvin monikulttuurinen, sillä on ollut islamilaisen, intialaisen, kiinalaisen ja siirtomaavala-aikakauden historialliset kaudet ja ne kaikki ovat jättäneet jälkensä maan rikkaaseen kulttuuriin. Monikulttuurisuus näkyi koko ajan paikallisessa puheessa ja käytännöissä ja antoi mallia eri kulttuurien ymmärtämiselle ja suvaitsevaisuudelle.

Parhaillaan maa on kehittymässä nopeasti vauraaksi hyvinvointivaltioksi sekä rikkaiden luonnonvarojen hyödyntämisen että kehittyvän osaamisen kautta. Paikalliset poliitikot korostivatkin avajaisissa kirjastojen merkitystä osaavan ja hyvinvoivan kansakunnan synnyttämisessä. Maa on sijoittanut vahvasti myös kirjastolaitoksensa kehittämiseen ja tämä näkyi myös runsaana paikallisten osallistumisena konferenssiin.

\section{IFLA:n muutosagenda}

IFLA aloitti vuonna 2017 globaalin visiotyöskentelyn järjestön vaikuttavuuden ja toimintatapojen kehittämiseksi. Tämän vuoden konferenssissa tuon keskustelun tuloksena julkaistiin raportti ja tuon raportin yhteenveto. Molemmat asiakirjat löytyvät IFLA:n Global vision -sivustolta, osoitteesta https://www.ifla.org/node/ I I 900. Vision toteuttamisen avuksi kerätään syksyllä 20 I 8 konkreettisia ideoita osoitteessa https://ideas.ifla.org/.

Visioraportin yhteenveto-osassa nostetaan esille kymmenen vahvuutta ja kymmenen mahdollisuutta kirjastoille. Tärkeimpänä havaintona on, että koko maailman kirjastoilla ja kirjastoseuroilla on yhteinen arvopohja, joka pohjautuu erityisesti haluun tarjota vapaa pääsy kaikille ihmisille informaation ja tietoon. Kirjastot ovat myös aktiivisia toimijoita yhteisöissään ja opettavat informaatiolukutaitoa eri 
tasoilla. Kirjastot näkevät lisäksi ole- teuttaa siten omaa visiotaan myös jovansa ihmiskunnan muistin säilyttä- kapäiväisessä toiminnassaan.

jiä ja ovat aktiivisia verkostoitujia ja Yleiskokouksessa päätettiin movaikuttajia alueillaan.

Suurimpina haasteina on ensinnäkin se, että poliittinen taistelu ilmaisun vapaudesta ei ole vieläkään päättynyt vaan maailmassa on edeleen alueita ja toimintaympäristöjä, joissa ihmiset eivät saa vapaasti esittää ja ajella mielipiteitään. Lisäksi digitaainen toimintaympäristö on tuonut tähän omia juridisia haasteita. Rahoitus, jolla taataan nykyaikaiset palvelut ja niiden jatkuva kehittäminen kaikille ja kaikkialla, näyttää myös olevan globaali ongelma kirjastoille. Tästä seuraa ehkä suurin haaste: kirjastojen tulee toimia entistä aktiivisemmin poliittisessa vaikuttamisessa ja käyttää siinä välineitä, joilla pystytään osoittamaan kirjastojen sivistyksellinen ja taloudellinen merkitys poliittisille päättäjille ja samalla sitoutetaan poliitikot rahoittamaan kaikille tarkoitettua kirjastolaitosta ja luomaan lainsäädäntöä, joka takaa yleisen tasa-arvon osaamisessa ja tiedon käytön mahdollisuuksissa. Käyttöluvut eivät riitä, vaan tarvitaan myös vakuuttavaa tarinankerrontaa.

Seura on aloittanut myös organiaationsa rakenteen muutosprosessin, osin visiotyön tuloksena. Tavoitteena on vähemmän byrokraattinen, ketterästi toimiva ja hallinnollisilta rakenteiltaan kevyempi järjestö. Järjestö on selkeästi myös alkanut aktiivisemmin kuunnella jäsenistöään kaikessa ja totaa yksilöjäsenten jäsenmaksua - tämä on kädenojennus kirjastolaisille, joilei ole esimerkiksi omaa kansallista katto-organisaatiota, joka toimisi välikätenä IFLA:n toimintaan osallistumisessa. Seuralla on selvästi halua kehittyä myös kaikkien kirjastolaisten omaksi ärjestöksi pelkkien kirjastojen ja kirjastoalan järjestöjen puolestapuhujana toimimisesta. Tällä päätöksellä on todennäköisesti merkittäviä seurauksia seuran käytänteisiin, jotka ovat perustuneet pitkälti instituutionaaliseen toimintaan.

\section{Digitaalinen humanismi ja \\ avoin tiede}

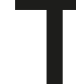

ieteellisten kirjastojen esityksissä olivat tänä vuonna agendalla erityisesti digitaalinen tiede ja sen kehittyminen ja kirjastojen rooli tässä kehityksessä. Digitaalisen humanismin session teemana olikin kirjastojen muuttuminen palveluiden tarjoajasta yhteistyökumppaniksi.

Tšekkiläinen Martin Lhoták esitteli eurooppalaisia digitaalisen humanismin hankkeita, joista keskeisimpänä on DARIAH-EU (https://www.dariah.eu/). DARIAH on yleiseurooppalainen infrastruktuuri taiteiden ja humanististen tutkijoiden kanssa, jotka työskentelevät tieteellisten laskentamenetelmien kanssa. Se tukee sekä digitaalista tut- kimusta että digitaalisten tutkimusmenetelmien opetusta.

Hänen mukaansa tällä hetkellä alkaa olla runsaasti digitaalisia aineistoja ja suurimpana haasteena onkin tätä aineistoa analysoivien menetelmi en - ja tutkijoiden tietoisuuden näistä menetelmistä - kehittäminen. Kirjas tojen erityiseksi tehtäväksi hän näk digitaalisten aineistojen pitkäaikaissäilyttämisen varmistamisen, ja digitoitujen aineistojen kohdalla digitaalisen $\mathrm{j}$ analogisen kokoelman yhdistämisen tutkijoiden työtä tukeviksi kokonaisuuksiksi.

Eteläafrikkalainen Theo Bothma korosti omassa esityksessään myös digitaalisen aineiston analyysivälineiden kehittämistä. Hänen oma kehitystyönsä on koskenut kirjallisia tekstejä ja lingvistiikkaa. Hän oli sitä mieltä, että kootut kokoelmat ja kirjastojen repositoriot eivät sinällään riitä, vaan niitä on rikastettava erityyppisellä metadatalla ja metadataa analysoimaan pystyvillä työkaluilla, esimerkiksi kielen kehityshistoriaa ja merkitysten monimuotoisuutta tukevilla analyysivälineillä. Erityisen tärkeitä ovat myös tilastolliset työkalut, joilla voidaan analysoid suuria datasettejä ja niiden sisältämiä merkityksiä.

Zhu Benjun Pekingin yliopistosta korostikin esityksessään, että olemme siirtymässä digitaalisista kirjastoista datakirjastoihin. Niiden hallinnassa myös hän painotti sitä, että kirjastojen tulee tehdä aktiivista yhteistyötä eri tieteenalojen tutkijoiden kanssa. Yhteiskuntatieteilijä ja humanisti kat soo ja tulkitsee samaa aineistoa eri tavoin: molempien tarvitsemia työkaluja tulee kehittää. Ennen kaikkea kirjastojen tulee kehittää yhteistyöverkostojaan eri tieteenalojen kanssa, jotta me ymmärtäisimme tukijoiden tarpeet ja tavoitteet digitaalisten aineistojen tutkimisessa. Digitaalisten kokoelmien kerääminen ja kuratointi tulee tehdä aina niin, että monitieteinen tutkimus mahdollistuu nyt ja tulevaisuudessa.

Avoimessa julkaisemisessa näyttäă myös olevan tapahtumassa muutos. Erityisesti kehitysmaiden edustajat keskustelivat aiheesta kriittisesti ja esittelivät hankkeitaan, joissa yliopistoista on tulossa avoimeen julkaisemiseen erikoistuneita kustantajia. Tämä niin kutsuttu avoimen kustantamisen timanttinen malli on erityisen toimiva ja tarpeellinen maissa, joissa opiskelijoilla ja kirjastoille ei ole varaa ostaa kalliita länsimaisten kaupallisten kustantajien aineistoja asiakkaidensa käyttöön.

Lisäksi esille nousi se, etteivät kaupalliset kustantajat ole edes kiinnostuneita kustantamaan lokalisoituja aineistoja, joista on eniten hyötyä paikallisille asiantuntijoille ja joiden lukija- ja ostajakunta ei ole laajaa. Hyvänä esimerkkinä eteläafrikkalaisen Reggie Rajun esityksen oppikirjat sekä afrikkalaisille kirurgeille että läkäreille HIV diagnosointia varten. Länsimaisen ki rurgian toimintaympäristöt ja tekniikat ovat vasta haaveita kehitysmaiden pai- 
kallisille toimijoille, joten oppikirjojen tulee palvella ja esitellä toimimista siinä toimintaympäristössä, jossa kulloinkin leikkauksia suoritetaan.

Avoin saatavuus on selkeästi myös ammattimaistumassa. Kirjastojen toimintatavat ja politiikat alkavat vakiintua ja muotoutua. Ja näyttää siltä, että vakava tiedekustantaminen kaikkine sen vaatimine rakenteineen ja palveluineen on tulossa takaisin tieteellisiin kirjastoihin, ainakin joillakin maailman alueilla.

\section{Aineistojen yhteiskäytön} muutokset

Aineistojen yhteiskäytön session aiheena oli kaukopalvelun muuttuva toimintakenttä. Indonesialainen Ali

Irhamni kertoi saarivaltion hankkeesta, jossa kirjastojen asiakkaat olivat saaneet käyttöönsä digitaalisia aineistoja. Tärkeänä teknisenä välineenä heillä oli digitaalisiin aineistoihin liittyvä ohjelmisto, joka hallitsi sekä aineistojen käytön, että käyttäjien oikeudet. Tämä oli mahdollistanut koko maan laajuisen digitaalisen aineiston jakelun suoraan käyttäjille.

Yhdysvaltalainen Greg Lucas kertoi puolestaan liittovaltiotasoisesta hankkeesta Kaliforniassa, jossa kirjastojen asiakkaat pystyivät ehdottamaan sitä, että heille ostettaisiin teos, jota ei ole kirjastojen kokoelmissa. Hankkeen rahoittajana on liittovaltio ja toimintatapana on tilata kirja Amazonin kautta, oka toimittaa sen suoraan asiakkaalle. Kirjan luettuaan asiakas palauttaa sen kirjastoon.

Lucasin ja hänen käyttämiensä asiakashaastatteluvideoiden mukaan toimintatapa on mahdollistanut asiakkaille sellaisen erikoisaineiston nopean saannin, jota erityisesti pienten kaupunkien kirjastojen kokoelmissa ei ole. Lisäksi hänen esittämien tilastotietojen mukaan tällainen kaukopalvelu on noin kaksi kolmannesta halvempaa kuin perinteinen. Lucas korosti kuitenkin, että tämä pätee edullisten ja kirjakaupasta saatavien aineistojen kohdalla - ostettujen kirjojen hinnalle oli asetettu katto ja esimerkiksi kalliita kurssikirjoja ei tällä hankkeella hankittu.

Session perusteella näyttää siltä, että ympäri maailmaa ollaan ottamassa uusia työtapoja ja tekniikoita kaukopalvelun ja aineistojen jakamisen käyttöön ja ne ovat alkaneet vaikuttaa myös kirjastojen kokoelmatyöhön ja sen periaatteisiin. Lisäksi brasilialaisten kollegojen esityksessä tuli esille, että erilaiset kansallisesti rahoitetut tieteen avoimen julkaisemisen hankkeet ovat avanneet paljon tieteellistä aineistoja kaikkien tarvitsijoiden käyttöön varsinkin kehittyvissä maissa.

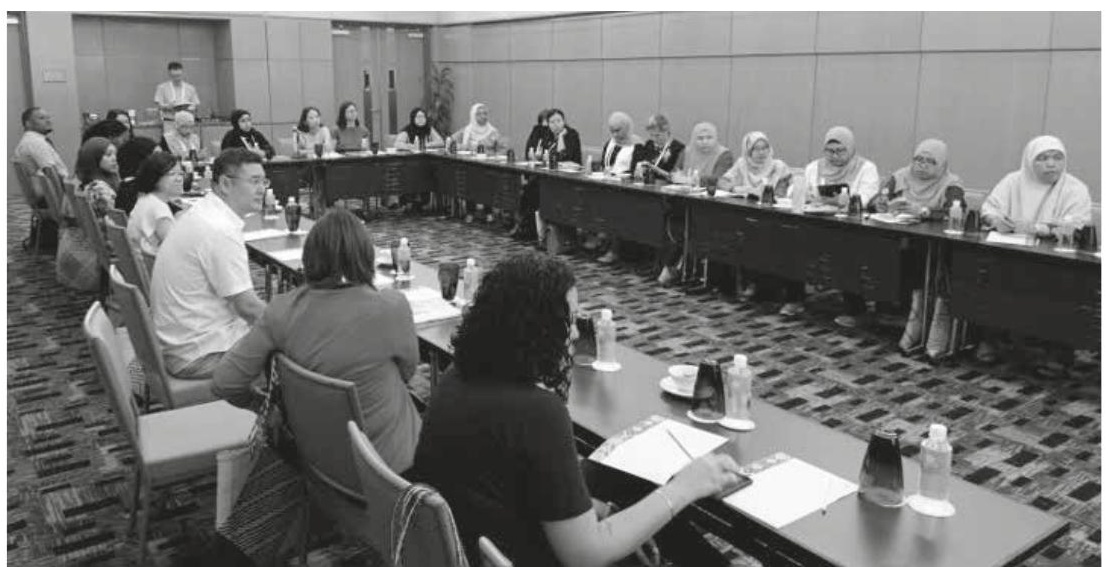

Inklusiivisiä kirjastoja

rakentamassa

K

jastorakennuksia käsittelevässä ohjelmassa toistuivat teema

"from collections to connections", "not place for books, place fo people" ja sekä muunneltavuus että joustavuus. Kirjastoja rakennetaan entistä enemmän kohtaamispaikoiksi ja jopa demokratiakehitystä tukeviksi makerspace-tiloiksi. Tässä näkyy myös niin kutsutun voimaannuttamis-ajattelun vaikutus: erityisesti yleiset kirjasto ovat vähitellen kehittymässä osaamisen ja kansalaistoiminnan monipuolisiks paikoiksi ja yleisiksi tiloiksi, jotka tarjoavat kaikille kansalaisille mahdollisuuden aktiiviseen ja vaikuttavaan osallisuuteen yhteiskunnassa. Vaikka esimerkit olivat pääosin yleisten kirjastojen puolelta, teemat ovat relevanttej myös tieteellisissä kirjastoissa, joissa erityisesti tekniset yliopistot ovat tehneet runsaasti vastaavanlaisia tilojen uudistus- ja kehittämishankkeita.

Inklusiivisuus tarkoittaa tilojen suunnittelussa sitä, että kaikkia henkilöitä ja toimijaryhmiä kohdellaan tasa-arvoisina kirjastotilojen käyttäjinä. Käytännön esimerkkinä voi pitää sitä, että kaikki pääsevät kulkemaan samasta pääovesta rakennukseen eikä pyörätuolin käyttäjille ole tehty erillistä ovea. Vähemmistöpuhetta vastaan on myös se tosiasia, että I $5 \%$ :lla eli noin miljardilla ihmisellä meistä on jonkinasteinen vamma tai este. Inklusiivinen kirjasto edellyttää Heidy Berthoudin (Vassar College Libraries, USA) listaa- masti erinomaisuutta arkkitehtuurissa, palveluista ja toiminnoissa, kokoelmissa sekä henkilökunnan osaamisessa.

Kehitystyöhön on tehty työkaluja kirjastolaisille. Designthinkingforlibraries.com antaa helpon askel askeleelta etenevän mallin palvelujen ja tilojen kehittämiseen. Suomessa hyvänä esi merkkinä on Helsingin uuden Oodi kirjaston suunnittelu, jossa käyttäjien kuuntelu ja tilojen suunnittelu näiden havaintojen mukaisesti loi aivan uudenlaisen käsityksen siitä, mitä kir jastotila ja sen tarjoamat palvelut voivat olla.

\section{Näkyvyyttä ja osaamisen}

kehittämistä

Jos miettii, mitä yleisiä tuomisia tieteelliselle kirjastoseuralle konferenssista oli, niin ehkä merkittävin seikka on näkyvyyden merkityksen korostuminen. Se tarkoittaa näkyvyyttä jäsenistön suuntaan ja vaikuttavaa näkyvyyttä seuran ulkopuolelle sekä kollegoiden kesken että erityisesti yhteiskunnallista näkyvyyttä ja sen lisäämistä. sTKs:n strategia huomioi nämä asiat ja on hyvä pohja käytännön työlle.

Yksi sessio käsitteli kirjastoseurojen roolia alan osaamisen kehittäänä antaen tästä esimerkkejä eri puolilta maailmaa. Yhteisen tekemisen muotoina nostettiin esiin mentorointi, yhteistyö kirjasto- ja informaatioalaa kouluttavien oppilaitosten kanssa sekä se, kuinka innostaa ihmisiä itse kehittämään osaamistaan. Suomen kirjastoseuran esityksessä mentoroitavat itse olivat 


\section{0}

$n$
$n$
$Z$
$C$
$z$
$w$
$n$
\pm
$N$
$\frac{0}{\infty}$
$\frac{0}{\infty}$

$\approx$ Hulppea konferenssi-

keskus sijaitsi Petronasin kaksoistornien juurella.

Posterit reunustivat Library avenueta. kertomassa toimintamallista ja omista kokemuksiaan prosessista. Mentoroinnin teemana oli kansainvälisyys ja joustava kevyt konsepti on helposti kopioitavissa myös tieteellisten kirjastojen käyttöön.

Kansainvälisessä toiminnassa oma merkityksensä on myös läsnäololla ja osallistumisella yleiseen viralliseen ja epäviralliseen keskusteluun. IFLA:n visiotyöskentely on tästä hyvä konkreettinen esimerkki, kuinka sitouttamalla laajoja joukkoja saadaan aikaiseksi myös sekä järjestön kehittämistä että poliittista vaikuttamista. Kirjastolaisilla on paljon annettavaa myös UNESCO:n 2030 ohjelman kehitystavoitteille, joissa koulutus, osaaminen ja tiedon saatavuus ovat keskeisiä elementtejä kestävän kehityksen rakentamisessa.

\section{Suomi näkyi}

Meitä suomalaisia oli Kuala Lumpurissa mukana parikymmenpäinen delegaatio kattavasti eri kirjastosektoreilta. Oli eri sektioiden toimintaan osallistujia, esityksen pitäjiä ja seurojen edustajia. Suomen kirjastoseuran puheenjohtajan, kansanedustaja Silvia Modigin esitelmä "Mindset change for the futures of li-

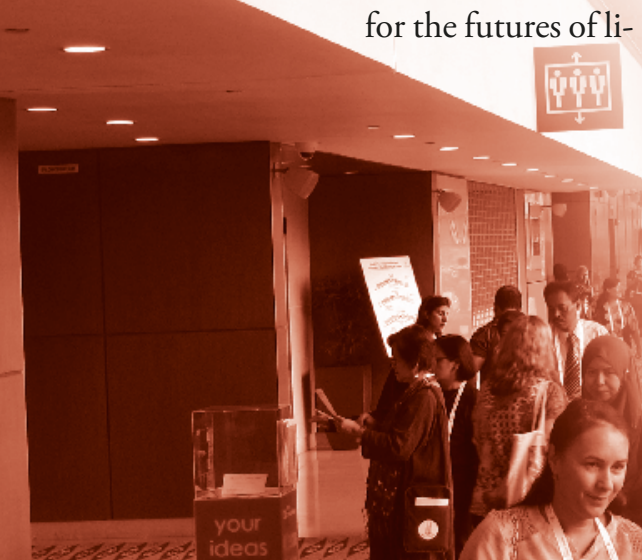

baries" noteerattiin paikallisessa mediassa. Joulukuussa avattava jo mainittu Oodi-keskustakirjasto sai konferenssissa huomiota muutenkin kuin Modigin esitelmän kautta. Vuoden 20 I 8 yleisen kirjaston tittelin voitti School 7 Hollannista. Oodi on varmasti vahvoilla ensi vuonna tässä kilpailussa.

Konferenssin päätösjuhlassa julistettiin Sinikka Sipilälle IfLa:n kunniajäsenyys ansioistaan toiminnassa IFLA:ssa ja kirjastoalalla yleensä.

Ensi vuoden IFLA-konferenssi järjestetään Ateenassa ja sitä seuraavana vuonna on tapahtumapaikka jälleen Euroopan ulkopuolella, Uudessa-Seelannissa. Arkisen työn ohella nämä konferenssit osoittavat, että kirjastoaate on vahva ja vahvistaa maailmaa. Kirjastot ja yhteiskunta kehittyvät käsi kädessä toisiaan kehittäen.

Ensi talven aikana käynnistyy myös komiteoiden ja työryhmien jäsenäänestykset toimikausien vaihtuessa. $\mathrm{Ne}$ antavat mahdollisuuden osallistua IFLA:n toimintaa syvällisemmin. Kannattaa seurata IFLA:n verkkoviestintää ja kysellä jo toiminnassa mukana olevilta kollegoilta lisätietoja, jos haluaa mukaan vaikuttamaan IFLA:n toimintaan.

\section{Risto HeikKinen}

Kehittämispäällikkö Avoimen tiedon keskus Jyväskylän yliopisto risto.v.heikkinen@jyu.fi 